\title{
MOKESČIO APSKAIČIAVIMAS TAIKANT TURINIO VIRŠENYBĖS PRIEŠ FORMĄ PRINCIPĄ
}

\author{
Egidija Puzinskaitè \\ Mykolo Romerio universiteto Ekonomikos ir finansų valdymo fakulteto \\ Finansų ir mokesčių katedra \\ Ateities g. 20, LT-08303 Vilnius, Lietuva \\ Telefonas (+370 5) 2714521 \\ Elektroninis paštas egidija@mruni.eu
}

Pateikta 2013 m. rugsèjo 2 d., parengta spausdinti 2013 m. gruodžio 4 d.

doi:10.13165/JUR-13-20-4-07

\section{Ivadas}

Lietuvos Respublikos Konstitucijos 127 straipsnio 2 ir 3 dalyse skelbiama, kad „valstybès biudžeto pajamos formuojamos iš mokesčių, privalomų mokejjimų, rinkliavų, pajamų iš valstybinio turto ir kitu ịplaukų. Mokesčius, kitas įmokas į biudžetus ir rinkliavas nustato Lietuvos Respublikos ịstatymai"1. Mokesčiai yra esminè valstybès finansų sistemos dalis. Jie sudaro pagrindinę valstybės biudžeto pajamų dali. Kad mokesčiai būtų efektyviai surenkami, nepakanka vien formaliai teisès aktais reglamentuoti mokestinių teisinių santykių dalyvių teisinį statusą.

Kovodama su mokesčiu vengimu, valstybè susiduria su rimtomis problemomis. İstatymai institucijoms, iggaliotoms administruoti mokesčius, suteikia daug teisių, iggalinančių nustatyti mokesčių įstatymų pažeidimus ir užtikrinti mokesčių, baudų, delspinigių sumokèjimą ị biudžetą ${ }^{2}$, tačiau lygiai taip pat svarbu, kad įstatymai mokesčių

1 Lietuvos Respublikos Konstitucija. Valstybès žinios. 1992, Nr. 33-1014.

2 Puzinskaitė, E. Mokestiniu ginču proceso teisiné analize. Daktaro disertacijos santrauka. Socialiniai mokslai, teisè (01S). Vilnius: Lietuvos teisès universitetas, 2002, p. 6. 
mokètojams suteiktų adekvačias ir pakankamas garantijas prieš galimus mokesčių administratoriaus pareigūnų pažeidimus, subalansuotų mokesčių administratoriaus ir mokesčių mokètojo teisinị statusąa ${ }^{3}$. Straipsnyje analizuojamas turinio viršenybès prieš formą principas yra viena iš teisinių priemonių užtikrinant teisingą mokesčių apskaičiavimą ir mokèjimą.

Turinio viršenybės prieš formą principo turinys Lietuvos mokesčių teisès doktrinoje yra praktiškai neanalizuotas, mokslinių tyrimų ir analizès šiuo klausimu nèra, iš esmès šis principas analizuotas ir apie jo reikšmę pasisakyta tik administracinių teismų ir Europos Teisingumo Teismo jurisprudencijoje. Apie ši principą savo darbuose yra užsiminę ir fragmentiškai pasisakę tokie Lietuvos mokesčių teisès specialistai kaip A. Medelienè, A. Paulauskas, B. Sudavičius, E. Puzinskaitè, V. Vasiliauskas ir užsienio mokslininkai De Broe, T. Grauberg, Z. Prebble, J. Prebble, F. Zimmer, A. Zalasinski. Tuo tarpu turinio viršenybės prieš formą principas dèl savo universalumo laikytinas pagrindine priemone prieš mokesčių vengimą Lietuvos mokestinejje praktikoje, todèl egzistuoja didelis poreikis šio principo taikomumą teoriniu ir praktiniu aspektais paanalizuoti kaip atskirą temą.

\section{Turinio viršenybės prieš formą principo istorinès ištakos ir samprata Lietuvoje, Vokietijoje, Olandijoje ir Belgijoje}

Turinio viršenybės prieš formą principo bendroji terminologija pradèta vartoti tik apie 1920-uosius metus ir tik visai neseniai šio principo taikymas tapo neatskiriama mokesčių sistemos dalimi ne tik Lietuvoje, bet ir daugelyje užsienio šalių. Šiuo metu minimo principo taikymas vienokia ar kitokia forma plinta skirtingų valstybių mokesčių sistemose, o jo atsiradimas yra siejamas su užsienio valstybėmis, tokiomis kaip Vokietija, Nyderlandai, JAV, kuriose šis principas pradètas sėkmingai taikyti. Šio principo praktinis taikymas laikytinas gana konfliktiška teisine priemone ir neteisingai ją taikant kyla mokesčių mokètojo teisètų interesų ir lūkesčių pažeidimo rizika. Be to, perteklinis turinio viršenybès prieš formą principo taikymas, manytina, prieštarautų apmokestinimo aiškumo principui. Šiuo metu galiojančiame mokesčių administravimo įstatyme įtvirtinant turinio viršenybès prieš formą principą, buvo remtasi Vokietijos, Naujosios Zelandijos bendrosiomis normomis, skirtomis piktnaudžiavimo prevencijai, taip pat Japonijos, Nyderlandų normų, susijusių su turinio ir formos principo taikymu, apžvalga bei JAV, Didžiosios Britanijos doktrinomis, susijusiomis su mokesčių vengimu, piktnaudžiaujant formos teikiamomis galimybėmis ${ }^{4}$.

Mokesčių administravimo įstatymo 10 straipsnis imperatyviai reikalauja, kad mokestiniuose teisiniuose santykiuose viršenybẻ būtų teikiama šių santykių dalyvių veiklos turiniui, o ne jos formaliai išraiškai, t. y. svarbus yra tikrasis ūkinès operacijos turinys, o ne šio turinio įforminimas. Sąžiningai veikiantis mokesčių mokètojas turi teisę bei galimybę numatyti savo veiksmų mokestines pasekmes ir pasirinkti tokị teisètą veiklos

3 Višinskis, V. Teismo sprendimu vykdymo procesinès problemos. Vilnius: Justitia, 1999, p. 8.

4 Psaros, J.; Trotman, K. T. The Impact of the Type of Accounting Standards on Preparers` Judgments. Abacus. 2004, 40(1) [interaktyvus]. <http://onlinelibrary.wiley.com>. 
modelį, kuris leistų vykdyti savo veiklą mažiausiomis išlaidomis, jei tik nėra pažeidžiamas draudimo piktnaudžiauti teise principas. Akcentuotina, jog tokios nuostatos, aiškinant vieno iš bendrujų teisès principų - draudimo piktnaudžiauti teise principo, turini, laikomasi ir Teisingumo Teismo praktikoje ${ }^{5}$. Aplinkybè, kad sudarydamas atitinkamus sandorius ar juose dalyvaudamas mokesčių mokètojas igijo tam tikrą mokestinị pranašumą, savaime nèra pagrindas konstatuoti, jog šie sandoriai buvo sudaryti piktnaudžiaujant mokesčių mokètojui suteiktomis teisèmis. Tuo tikslu būtina nustatyti igyjamo mokestinio pranašumo prieštaravimą mokesčių įstatymų nuostatomis siekiamam tikslui, taip pat nustatyti objektyvių požymių visumą, kuri patvirtintų, kad nagrinėjamų sandorių pagrindinis tikslas yra igyti mokestinị pranašumą ${ }^{6}$. Mokesčio apskaičiavimui taikant turinio viršenybès prieš formą principą, būtina nustatyti, kad sandoris, ūkinė operacija ar bet kokia jų grupè sudaryta turint tikslą gauti mokestinę naudą.

Mokesčių mokètojai tam tikrais atvejais sandorius sudaro tik dẻl akių, jų realiai nevykdo arba neivvykdo, o juos (sandorius) ir jų pagrindu išrašytus fiktyvius apskaitos dokumentus, siekdami mokestinès naudos, naudoja, pavyzdžiui, apmokestinamoms pajamoms iš kitų šaltinių pagrịsti, ị apskaitą ịtraukti nepatirtas išlaidas ir pan. Taip pat susiduriama su atvejais, kai, siekiant tam tikros mokestinès naudos, ịvykę sandoriai įforminami taip, kad formali jų išraiška neatitinka realaus jų ekonominio (socialinio) turinio, t. y. atitinkamais sandoriais yra pridengiami kiti sandoriai, kito pobūdžio ir turinio ūkinès operacijos nei formaliai užfiksuotos, todèl nustačius šias aplinkybes, atsiranda prielaida taikyti turinio viršenybės prieš formą principą ${ }^{7}$.

Turinio viršenybès prieš formą principo kaip mokesčių priemonès prieš mokesčių vengimą ištakos siejamos su romėnų teisèje žinomu piktnaudžiavimo teise (fraus legis) principu, pagal kurị asmuo negali tikètis teisinès apsaugos, jeigu jis siekia gauti naudos nesąžiningu būdu naudodamasis jam priklausančia subjektyvine teise ${ }^{8}$. Būtent šis privatinès teisès principas tapo mokesčių vengimo prevencijos priemone, ịtvirtinta šiuolaikinèje mokesčių teisejje ir naudojama teismų praktikoje ${ }^{9}$. Šiuolaikiniame pasaulyje turinio viršenybės prieš formą principas tapo neatsiejama taikomų priemonių prieš mokesčių vengimą dalis. Ne vienoje šalyje jų taikymo pagrindą sudaro civilinèje teisèje suformuluoti principai ir atitinkami teismų precedentai mokestinių ginčų bylose. Prie tokių šalių pirmiausia priskirtinos Jungtinès Amerikos Valstijos, Jungtinė Karalystė, Olandija, Prancūzija, Norvegija ${ }^{10}$.

5 Europos Teisingumo Teismo 2010 m. gruodžio 22 d. sprendimas byloje Weald Leasing Ltd. Nr. C-103/09 [interaktyvus]. [žiūrèta 2013-11-04]. <http://eur-lex.europa.eu> .

6 Lietuvos vyriausiojo administracinio teismo $2011 \mathrm{~m}$. vasario $23 \mathrm{~d}$. nutartis administracinejje byloje Nr. A A $^{575}-371 / 2011$ [interaktyvus]. [žiūrèta 2013-10-16]. <www.lvat.lt>.

7 Puzinskaitè, E.; Klišauskas, R. Mokesčių teisès sistema ir apmokestinimo principai. Jurisprudencija. 2012, 19(2): 675-695.

8 Zalasinski, A. Proportionality of Anti-Avoidance and Anti-Abuse Measures in the ECJ Direct Tax Case Law. Interfax. 2007, (35)5 [interaktyvus]. [žiūrèta 2013-11-20]. <http://books.google.lt>.

9 Grauberg, T. Anti-tax-avoidance Measures and Their Compliance with Community Law. Juridica International. 2009, Num. XVI, p. 141.

10 Gregory, V. Helvering 293 U.S 465 (19350). Justia: US Supreme Court Center [interaktyvus]. [žiūrèta 2013-11-21]. < https://supreme.justia.com/cases $>$. 
Ypač dažnai turinio viršenybės prieš formą principą taiko mokesčių administratoriai anglosaksų teisės tradicijų šalyse. Jungtinès Karalystės teismų praktikoje dominuoja pozicija, kad, nustatant apmokestinimo objektą, būtina atsakyti, ar sandoris apsimestinis, ar fiktyvus, ar tokia netinkama sandorio forma buvo pasirinkta mokesčių vengimo tikslu. Kitaip kalbant, mokesčių administratorius privalo pripažinti neapsimestinį ir nefiktyvų sandorị ${ }^{11}$.

Tačiau šiai doktrinai taikyti mokestinejje praktikoje nepakanka išvados, kad sutartiniai santykiai yra apsimestiniai. Būtina nustatyti, kad tai leidžia mokesčių mokètojui sumažinti mokestinę naštą. Pradedant nuo 1980 m., Jungtinès Karalystės teismų praktikoje daugiau dèmesio skiriama sandorių tikslui ir ekonominiam turiniui. Turinio viršenybės koncepcija čia dažnai vadinama Ramsio doktrina, pagal kurią, nustatant sandorio tikslą, būtina rasti faktinių aplinkybių, atitinkančiu apmokestinimo ekonominį turinį ${ }^{12}$.

Vokietijoje ir kitose šalyse, orientuotose ị šios šalies teisinę tradiciją, taip pat kaip priemonè prieš mokesčių vengimą taikomas turinio viršenybès prieš formą metodas, kai sandorio interpretavimas nesaistomas sandorio ịvardijimu pagal civilinès teisès normas. Vokietijos mokesčių kodekso 42 straipsnyje nustatyta, kad mokesčių ịstatymas negali būti apeinamas piktnaudžiaujant tesès suteikiamomis galimybèmis. Piktnaudžiavimo atveju apmokestinimas grindžiamas sandorio ekonominiu turiniu ${ }^{13}$. Vokietijos teismų praktikoje ši norma taikoma nustačius kelis elementus: pirma, mokesčių mokètojo pasirinkta teisinè sandorio forma - neadekvati, o šis neadekvatumas savo ruožtu reiškia, kad nešališka trečioji šalis negalètų dalyvauti tokiame sandoryje tomis pačiomis sąlygomis. Antra, mokesčių mokètojo pasirinkta teisinè sandorio forma akivaizdžiai patenka ị geresnį mokestinị režimą nei adekvatus sandoris. Trečia, nėra priimtino pateisinimo, kodèl buvo pasirinkta tokia sandorio forma. Ketvirta, subjektyvus tikslas sumažinti mokestinę naštą. Kai visi keturi elementai nustatyti, sandoris gali būti interpretuojamas apmokestinimo tikslais. Vokietijos teismai šị nepalankų mokesčių mokètojui interpretavimo būdą taiko tik po to, kai išnaudojamos galimybès paaiškinti sandorị palankiai - taikant gramatinị ir sisteminị metodus, atsižvelgiant ị galimas ypatingas aplinkybes ${ }^{14}$.

Kiek kitokios praktikos laikomasi Belgijoje, kur teisinè sandorio forma yra daug reikšmingesnè. Remiantis nuostata, įtvirtinta belgiškoje mokesčių teisèje, sandorių apibrěžimai, naudojami privatinejje teisèje, turi būti pripažįstami. Mokestinèmis procedūromis negalima kištis ị civilinị teisinị sandorio vertinimą. Šis požiūris grindžiamas Belgijos Konstitucijos 170 straipsniu, skelbiančiu, kad ị biudžetą mokami mokesčiai gali būti nustatyti tik įstatymu ${ }^{15}$. Ši taisyklè aiškinama siaurinamai ir mokesčių administratorius privalo remtis reguliavimu, tiesiogiai nurodytu mokesčių įstatymuose. Šią mokesčių mokètojui palankią poziciją suformulavo Belgijos Aukščiausiasis Teismas, atmetęs ekonominio turinio viršenybès doktriną. Kita vertus, šios šalies teismai palaiko poziciją,

11 Prebble, Z.; Prebble J. Comparing the General Anti-Avoidance Rule of Income Tax Law with the Civil Law Doctrine of Abuse of Law. Bulletin of International Taxation. 2008, p. 167. 
kad mokestinės atsakomybės taikymui svarbu, ar sandoris yra apsimestinis, ar tikras, nes apsimestinis sandoris pagal civilinès teisès doktriną nesukelia teisinių pasekmių. Taigi Belgijoje sudarytos palankios sąlygos planuoti mokesčius. Iৃvairios mokesčių naštos mažinimo schemos gali būti pakankamai sėkmingos, kol mokesčių administratorius neįrodys, kad sandoris apsimestinis ir juo siekiama vengti mokesčių ${ }^{16}$. Paminėtinos ir šios šalies įstatymo leidejjo pastangos sugriežtinti situaciją. $1993 \mathrm{~m}$. buvo priimta Belgijos mokesčių kodekso pataisa (344-1 str.), pagal kurią šalių pasirinkta sandorio charakteristika nesaisto mokesčių administratoriaus, jeigu jis nustato, kad ši charakteristika nukreipta į mokesčių vengimą ir mokesčių mokètojas neįrodo, kad ji pateisinama teisètais finansinio ar ekonominio pobūdžio poreikiais ${ }^{17}$. Tai literatūroje traktuojama kaip žingsnis nuo tradicinès Belgijoje teisinès formos viršenybès doktrinos link fraus legis doktrinos, kuri iš esmès atitinka ir turinio viršenybès prieš formą principą.

Olandijos mokesčiu ịstatyme suformuluota norma, t. y. 31 straipsnis, leidžiantis mokesčių administratoriui nesilaikyti sandorio formos, sudarytos mokesčių vengimo tikslais. Ši priemonė praktikoje taikoma gana retai, dažniau taikoma Aukščiausiojo Teismo sprendimu ịtvirtinta fraus legis doktrina, kuri suteikia prioritetą ịstatymo esmei, bet ne žodžiams, kuriais įstatymas apibūdintas ${ }^{18}$. Teismas tiki, kad mokesčių vengimas gali būti preziumuojamas, jeigu mokesčių mokètojo veiksmai neturi verslo motyvo ir gauta mokestinè nauda prieštarauja ịstatymo esmei. Toks sandoris gali būti peržiūrètas ir ịvertintas pagal artimiausią šiam sandoriui teisinị turinị, taip pašalinant abejones dèl piktnaudžiavimo teise. Taigi pagal olandišką požiūrị faktinès aplinkybès turi būti analizuojamos taip, kad nebūtų abejonių dèl jų teisinio atitikimo apmokestinamam objektui. Tos analizès metu nustatoma, ar sandorio forma atitinka civilinès teisès principus ir ekonominị turinį.

Apibendrinant tai, kas anksčiau išdèstyta, darytina išvada, kad turinio viršenybès prieš formą principas gali būti taikomas, ịvertinus subjektyvųji sandorio tikslą, ekonominị sandorio turinị, pasirinktą teisinę sandorio formą ir jos adekvatumą konkrečioms sąlygoms, sandorio pateisinimą - verslo motyvą, mokestinę naudą.

Palankiausiai mokesčių mokètojui turinio viršenybès prieš formą principas aiškinamas Belgijoje, nes mokestinėmis priemonėmis draudžiama kištis ị civilinị teisinị sandorio vertinimą.

\section{Mokesčių mokètojo pareiga apskaičiuoti mokesčius}

Kaip skelbia Mokesčių administravimo įstatymo 40 straipsnio 1 punktas, mokesčiu mokètojas privalo laiku ir tiksliai ịvykdyti mokestinę prievolę ${ }^{19}$, t. y. mokesčio įstatymo nustatytu pagrindu teisingai apskaičiuoti ir laiku sumokèti mokestị bei su juo susijusias

16 De Broe, L. International Tax Planning and Prevention of Abuse. Amsterdam, 2008 [interaktyvus]. [žiūrèta 2013-11-21]. < http://www.ibfd.org>.

17 Belgiian Incom Tax Code. 1992 [interaktyvus]. [žiūrèta 2013-11-19]. < http://www.expatica.com.>.

18 Zimmer, F., supra note14.

19 Lietuvos Respublikos mokesčių administravimo įstatymas. Valstybès žinios. 2004, Nr. 63-2243. 
sumas ị biudžetą, taip pat atlikti kitas pareigas, susijusias su mokesčio apskaičiavimu ir sumokèjimu. Tam, kad mokesčio mokètojas galètų tinkamai vykdyti jam tenkančią mokestinę prievolę, jis turi aiškiai žinoti atitinkamo mokesčio bazę ir nuo jos priklausančią jam mokèti ị biudžetą mokesčio sumą. Todèl galima teigti, kad mokestinès prievolès vykdymo procesas prasideda nuo mokesčio apskaičiavimo ir deklaravimo. Mokesčio apskaičiavimo esmę sudaro mokètinos ị biudžetą mokesčio sumos nustatymas atsižvelgiant i mokesčio bazę ir pritaikius jai mokesčio ịstatyme nustatytą mokesčio tarifą ${ }^{20}$. Mokesčių mokètojo pareiga apskaičiuoti mokesčius yra ịtvirtinta Mokesčių administravimo įstatymo 66 straipsnio 1 dalyje. Šioje nuostatoje įtvirtinta, jog vadovaudamasis mokesčių teisès aktais, priklausanti mokèti mokestị mokesčių mokètojas apskaičiuoja pats, išskyrus atitinkamuose mokesčių teisès aktuose numatytas išimtis. Pastebejjęs, kad mokestis buvo apskaičiuotas neteisingai, mokesčių mokètojas ji perskaičiuoja. Kaip matyti iš įstatymo nuostatų, mokesčių mokètojas turi pareigą pats teisingai apskaičiuoti mokestị. Jeigu mokesčių mokètojui, vykdant šią pareigą, iškyla neaiškumų, jis gali kreiptis konsultacijos i mokesčių administratorių ${ }^{21}$.

Mokesčių administravimo įstatymo 66 straipsnio 3 dalis ịtvirtina, jog Mokesčių administravimo įstatyme, jei jo atitinkamuose straipsniuose nenustatyta kitaip, vartojama mokesčio apskaičiavimo sąvoka apima ir mokestị išskaičiuojančio asmens atliekamą mokesčių išskaičiavimą. Tais atvejais, kai mokesčių mokètojas teisès aktų nustatyta tvarka neapskaičiavo mokesčio arba neteisingai apskaičiavęs jo neperskaičiavo, mokesčių mokètojui priklausantị mokèti mokestị apskaičiuoja mokesčių administratorius, remdamasis mokesčių mokètojo pateiktomis mokesčių deklaracijomis, apskaitos bei kitais dokumentais arba kitais Mokesčių administravimo įstatyme numatytais specialiais mokesčių apskaičiavimo būdais ${ }^{22}$.

\subsection{Mokesčių apskaičiavimo ir perskaičiavimo senatis}

Mokesčių administravimo įstatymo 68 straipsnio 1 dalis nustato, jog, jeigu kitaip nenustatyta atitinkamo mokesčio įstatyme, mokesčių mokètojas ar mokesčių administratorius mokestị apskaičiuoti arba perskaičiuoti gali ne daugiau kaip už einamuosius ir penkerius praėjusius kalendorinius metus, skaičiuojamus atgal nuo tų metų, kai pradedama mokestị apskaičiuoti arba perskaičiuoti, sausio 1 dienos. Mokestiniuose ginčuose mokesčio apskaičiavimo ir perskaičiavimo senatis privalo būti taikoma ex officio (savo iniciatyva), o to nepadaręs mokestinių-teisinių santykių dalyvis, laikytina, pažeidè Mokesčių administravimo įstatymo 68 straipsnio 1 dalị ${ }^{23}$. Aptariamas senaties terminas neriboja mokesčių administratoriaus teisès nustatyti ir vertinti ị ši terminą nepatenkančias faktines aplinkybes, kurios yra reikšmingos apskaičiuojamiems (perskaičiuojamiems) mokesčiams ir susijusioms sumoms. Akcentuotina, jog nei Mokesčių administravimo

20 Medeliené, A.; Sudavičius, B. Mokesčiu teisè. Vilnius: Registrų centras, 2011, p. 188.

21 Lietuvos Respublikos mokesčių administravimo įstatymas, supra note 19.

22 Lietuvos Respublikos mokesčių administravimo ịstatymas, supra note 19.

23 LVAT $2005 \mathrm{~m}$. balandžio 27 d. nutartis administracinèje byloje Nr. A ${ }^{15}-485 / 2005$ [interaktyvus]. [žiūrèta 2013-10-08]. <www.lvat.lt>. 
įstatymas, nei kiti įstatymai nenumato jokių apribojimų tiek mokesčių mokètojui, tiek mokesčių administratoriui apskaičiuojant bei perskaičiuojant mokesčius už tam tikrą mokestini laikotarpi remtis (vadovautis) papildoma įrodomaja medžiaga, kurioje užfiksuotos ankstesniais laikotarpiais atsiradusios faktinès aplinkybės, svarbios teisingam mokesčio apskaičiavimui (perskaičiavimui) ${ }^{24}$.

Mokesčio apskaičiavimo ar perskaičiavimo senaties skaičiavimo termino pradžia sietina su mokesčių mokètojo patikrinimo pradžia, kuria laikytinas pavedimo tikrinti išrašymo faktas (momentas). Mokestinis patikrinimas iš esmès yra mokesčių administratoriaus atliekamas mokesčių mokėtojo vykdomo mokesčių apskaičiavimo patikrinimas (Mokesčių administravimo įstatymo 2 str. 21 d.) ${ }^{25}$. Visa mokestinio patikrinimo procedūra yra nukreipta būtent ị mokesčių apskaičiavimą ar perskaičiavimą, todèl pradejjus mokestinị patikrinimą kartu pradedamas ir mokesčių administratoriaus vykdomas mokesčių apskaičiavimas ar perskaičiavimas ${ }^{26}$.

Apibendrinant tai, kas anksčiau išdėstyta, darytina išvada, kad Mokesčio apskaičiavimo senaties termino pradžia yra pavedimo tikrinti mokesčių mokètoją ar mokestị išskaičiuojanti asmenị išrašymo momentas.

\section{Mokesčio apskaičiavimo teisingumo pagrindimas}

\subsection{Mokesčių administratoriui tenkanti įrodinèjimo našta}

Vadovaujantis Mokesčių administravimo įstatymo 67 straipsnio 1 dalimi, mokesčių administratorius privalo pagrįsti jo mokesčių mokètojui apskaičiuotas mokesčio ir su juo susijusias sumas. Jokie teisès aktai nenustato dokumentų, kuriais mokesčių administratorius gali grịsti apskaičiuotus mokesčius, sąrašo, todèl mokesčių mokètojui apskaičiuotos mokesčio ir su juo susijusios sumos gali būti grindžiamos įrodymų leistinumo kriterijus atitinkančiais dokumentais ${ }^{27}$. Mokesčių administratorius apskaičiuodamas mokesčius privalo remtis objektyvia informacija, nustatoma renkant ir nešališkai vertinant visus įrodymus. Visų pirma mokesčių administratorius turi turèti atitinkamus įrodymus priimdamas ir grịsdamas savo sprendimus.

\subsection{Mokesčių mokètojui tenkanti įrodinèjimo našta}

Pagal bendrają taisyklę, mokesčių mokètojas, nesutinkantis su mokesčių administratoriaus apskaičiuotomis konkrečiomis mokesčio ir su juo susijusiomis sumomis, privalo pagrįsti, kodèl jos yra neteisingos ${ }^{28}$, todèl nustačius, kad mokesčių administrato-

24 LVAT $2011 \mathrm{~m}$. vasario $4 \mathrm{~d}$. nutartis administracinëje byloje Nr. A ${ }^{438}-201 / 2011$, ibid.

25 Puzinskaitè, E. Mokesčių mokètojo patikrinimas. Jurisprudencija. 2003, 38(30): 111-121.

26 LVAT $2009 \mathrm{~m}$. lapkričio 30 d. nutartis administracinèje byloje Nr. A ${ }^{442}-1431 / 2009$ [interaktyvus]. [žiūrèta 2013-10-08]. <www.lvat.lt>.

27 LVAT $2011 \mathrm{~m}$. gegužès $24 \mathrm{~d}$. nutartis administracinėje byloje Nr. A ${ }^{442}-1427 / 2011$, ibid.

28 Lietuvos Respublikos mokesčių administravimo įstatymas, supra note 19. 
rius pateikè pakankamai duomenų, irodančių mokesčio ir su juo susijusių sumų apskaičiavimo pagrịstumą bei teisingumą, mokesčiu mokètojui, kuris nesutinka su mokesčių administratoriaus apskaičiavimu, tenka pareiga įrodyti, jog mokesčių administratorius neteisingai apskaičiavo mokesčio ir su juo susijusias sumas. Jeigu mokesčių moketojas neįvykdo šios pareigos, tai nustačius, jog mokesčiu administratorius pagrindė mokesčių mokètojui apskaičiuotą mokestį ir su juo susijusias sumas, mokesčių moketojui atsiranda mokestinè prievole $\dot{e}^{29}$. Sąvoka ,pagrịsti“ gali būti vartojama dviem aspektais. Pirmuoju aspektu, sąvoka „pagrịsti“ reiškia pateikti tokius argumentus, kurie patvirtintų, jog mokesčių administratoriaus surinkta ir ištirta medžiaga, leidžia daryti išvadą, kad pats mokestis buvo apskaičiuotas neteisingai arba neteisingai nustatyta mokesčio bazè, interpretuotos faktinès aplinkybės ar pritaikytos materialinès teisès normos. Kitu aspektu, sąvoka „pagrissti“ gali reikšti, kad mokesčio ar jo dydžio apskaičiavimo neteisingumui patvirtinti yra pateikiami nauji įrodymai, kuriais grindžiamas mokesčio mokètojo reikalavimas $^{30}$.

Kai mokesčių administratorius yra surinkęs atitinkamus faktinius duomenis ir jais grindžia apskaičiuotus papildomus mokesčius bei su jais susijusias sumas, mokesčių mokètojui apsiginti galimybè atsiranda, kai jis savo ruožtu teikia kitokius faktinius duomenis, suponuojančius priešingą nei mokesčių administratoriaus padarytą išvadą. Apsiribojimas vien teiginiais, atsikirtimais, nepagrịstais jokiais ịrodymais, negali nulemti sprendimo prièmimo mokesčių mokètojo naudai. Mokesčių mokètojui siekiant paneigti apskaičiuotas sumas bei nuginčyti mokesčiu administratoriaus sprendimą, nepakanka apsiriboti įrodymais nepagrịstų paaiškinimų, kontrargumentų teikimu. Mokesčių mokètojas turètų pateikti tokius įrodymus, kurie suponuotų priešingą išvadą, nei daro mokesčių administratorius. O tuo atveju, kai nepakanka įrodymų patvirtinti nei mokesčių mokètojo, nei mokesčiu administratoriaus nurodomas aplinkybes, sprendimas priimtinas tos šalies nenaudai, kuriai priklauso neįrodytų aplinkybių įrodinėjimo našta ${ }^{31}$.

Apibendrinant teigtina, jog tais atvejais, kai nepakanka įrodymų patvirtinti nei mokesčiu mokètojo, nei mokesčių administratoriaus nurodomas aplinkybes, sprendimas priimtinas tos šalies nenaudai, kuriai priklauso neịrodytų aplinkybių ịrodinėjimo našta.

\section{Mokesčio apskaičiavimas taikant turinio viršenybès prieš formą principą}

Apskaičiuojant mokestį, turinio viršenybès prieš formą principas taikytinas tuomet, kai yra nustatyta, kad sandorị, ūkinę operaciją ar jų grupę mokesčio mokètojas sudarè turèdamas tikslą gauti mokestinę naudą, t. y. tiesiogiai ar netiesiogiai nukelti mokesčio mokejjimo terminus, sumažinti mokètiną mokesčio sumą, išvengti mokesčio mokẻjimo,

29 LVAT $2011 \mathrm{~m}$. vasario $14 \mathrm{~d}$. nutartis administracinejje byloje Nr. A ${ }^{438}-147 / 2011$ ir $2011 \mathrm{~m}$. gegužè $24 \mathrm{~d}$. nutartis administracineje byloje Nr. $\mathrm{A}^{442}-1427 / 2011$, ibid.

30 LVAT $2005 \mathrm{~m}$. spalio $5 \mathrm{~d}$. nutartis administracineje byloje Nr. A 15-1280/2005; $2010 \mathrm{~m}$. spalio $25 \mathrm{~d}$. nutartis administracineje byloje Nr. A $438-1147 / 2010$, ibid.

31 LVAT $2010 \mathrm{~m}$. rugsèjo $13 \mathrm{~d}$. nutartis administracinèje byloje Nr. A ${ }^{556}-1023 / 2010$ [interaktyvus]. [žiūrèta 2013-10-08]. <www.lvat.lt>. 
padidinti grąžintiną (įskaitytiną) mokesčio permoką (skirtumą) ar sutrumpinti mokesčio permokos (skirtumo) grąžinimo terminus. Taikydamas nurodytą principą, mokesčių administratorius neatsižvelgia ị formalią mokesčių mokètojo veiklos išraišką, bet atkuria iškreipiamas ar slepiamas aplinkybes, ir mokestị apskaičiuoja pagal minètų mokesčių įstatymų atitinkamas nuostatas (Mokesčių administravimo įstatymo 69 str. 1 d.) $)^{32}$.

Europos Teisingumo Teismas šiuo klausimu yra pažymėjęs, kad kvalifikuojant sandorị kaip apmokestinamajj, turi būti atsižvelgiama ị ekonominę ir komercinę realybę, siekiant patenkinti teisinio saugumo reikalavimus, ir jei paaiškejja, jog sutarties nuostatos yra vien dirbtinis susitarimas, kuris neatspindi sandorių ekonominès ir komercinès realybės, sutarties nuostatos turi būti apibrèžtos iš naujo taip, kad būtų atkurta situacija, kuri būtų egzistavusi nesant piktnaudžiaujant sudarytų sandorių ${ }^{33}$.

Siekiant konkrečiai situacijai taikyti Mokesčių administravimo įstatymo 69 straipsnio 1 dalies nuostatas, būtina nustatyti, jog mokesčių mokètojas, sudarydamas atitinkamus sandorius ar vykdydamas tam tikras ūkines operacijas, siekè vienintelio tikslo - gauti mokestinę naudą. Kai objektyviai nustatoma, kad atitinkamas sandoris (ūkinè operacija) turejjo kitus, ekonomiškai arba kitaip pagrịstus tikslus, nurodyta norma negali būti taikoma net ir tuo atveju, kai mokesčio mokètojas turèjo iš šio sandorio (ūkinès operacijos) atitinkamą mokestinę naudą ${ }^{34}$.

Reiktų pažymèti ir tai, kad joks teisès aktas neịpareigoja mokesčių mokètojo, esant galimybei pasirinkti vieną iš kelių teisèto elgesio modelio variantų, rinktis tokị, pagal kurị jam atsirastų didžiausia mokestinè prievole $\dot{e}^{35}$. Istatymai taip pat neịpareigoja (nenustato prievolès) rinktis tokị turto perleidimo (sandorių sudarymo) būdą, kuris būtų naudingiausias valstybès biudžetui. Sąžiningai veikiantis asmuo (teisès subjektas, mokesčių mokètojas) turi teisę bei galimybę numatyti savo veiksmų mokestines pasekmes ir pasirinkti tokị teisètą veiklos modelị, kuris leistų vykdyti savo veiklą mažiausiomis išlaidomis, jei tik nèra pažeidžiamas draudimo piktnaudžiauti teise principas. Akcentuotina, jog tokios nuostatos, aiškinant vieno iš bendrujų teisės principų - draudimo piktnaudžiauti teise principo - turinị, laikomasi ir Teisingumo Teismo praktikoje ${ }^{36}$. Vien ta aplinkybè, kad sudarydamas atitinkamus sandorius ar juose dalyvaudamas mokesčių mokètojas igijo tam tikrą mokestini pranašumą, savaime nėra pagrindas konstatuoti, jog šie sandoriai buvo sudaryti piktnaudžiaujant mokesčių mokètojui suteiktomis teisèmis. Tuo tikslu būtina nustatyti ịgyjamo mokestinio pranašumo prieštaravimą mokesčių įstatymų nuostatomis siekiamam tikslui, taip pat nustatyti objektyvių požymių visumą,

32 Lietuvos Respublikos mokesčių administravimo įstatymas, supra note 19.

33 Europos Teisingumo Teismo 2013 m. birželio 20 d. sprendimas byloje Alabaster Nr. C-653/11 [interaktyvus]. [žiūrèta 2013-11-04]. <http://eur-lex.europa.eu>.

34 LVAT $2008 \mathrm{~m}$. vasario $20 \mathrm{~d}$. sprendimas administracinëje byloje Nr. A556-250/2008, taip pat $2007 \mathrm{~m}$. liepos $17 \mathrm{~d}$. nutartis administracinejje byloje Nr. A11-719/2007, $2013 \mathrm{~m}$. vasario $5 \mathrm{~d}$. nutartis administracinèje byloje Nr. A602-705/2013 ir 2013 m. vasario 19 d. nutartis administracinejje byloje Nr. A556-618/2013 [interaktyvus]. [žiūrèta 2013-10-09]. <www.lvat.lt>.

35 Puzinskaitè, E. Relation of civil case with the procedure of taxinspection and tax dispute in the process of identification and investigation of shelter enterprises. The problems of the financial law evolution in central and eastern Europe within the integration processes. Vilnius-Bialystok, 2004, p. 70.

36 Europos Teisingumo Teismo 2010 m. gruodžio 22 d. sprendimas byloje Weald Leasing Ltd. Nr. C-103/09 [interaktyvus]. [žiūrèta 2013-11-04]. <http://eur-lex.europa.eu>. 
kuri patvirtintų, kad nagrinejjamų sandorių pagrindinis tikslas yra ịgyti mokestinị pranašumą ${ }^{37}$.

Apibendrinant darytina išvada, kad mokesčio apskaičiavimui, taikant turinio viršenybès prieš formą principą, būtina nustatyti, kad sandoris, ūkinė operacija ar bet kokia jų grupė sudaryta turint tikslą gauti mokestinę naudą, o atsižvelgiant ị Mokesčių administravimo ịstatymo 67 straipsnio 1 dalies nuostatas, pagrịsti tvirtinimą, kad sandoriai sudaryti siekiant mokestinès naudos, privalo mokesčių administratorius ${ }^{38}$. Todèl ginčui pasiekus teismą, jis turi nustatyti, ar mokesčių administratoriaus išvada dèl tikrojo ginčo sandorio (ūkinès operacijos) turinio yra pagrịsta tinkamu faktinių aplinkybių vertinimu ir pakankamais įrodymais ${ }^{39}$.

Sandoriai ir ūkinès operacijos, sudaromi siekiant mokestinès naudos, pasižymi didele ịvairove. Kaip jau anksčiau buvo minèta, mokesčiu mokètojai tam tikrais atvejais sandorių realiai ne(i)vykdo, o sandorius ir jų pagrindu išrašytus fiktyvius apskaitos dokumentus, siekdami mokestinès naudos, naudoja, pavyzdžiui, apmokestinamoms pajamoms iš kitų šaltinių pagrịsti, ị apskaitą ịtraukti nepatirtas išlaidas ir pan., todèl nustačius minètas aplinkybes, atsiranda prielaida taikyti turinio viršenybės prieš formą principą. Akcentuotina, kad išvados apie mokesčio mokètojo tam tikrų civilinių sandorių pagrindu gautų pajamų realumą darytinos tik sistemiškai bei kompleksiškai ịvertinus visus tiesioginius bei netiesioginius ịrodymus, pagrindžiančius ar paneigiančius objektyvų pajamų gavimo faktą. Vien atskirų formalių ịrodymų (pvz., paprasta rašytine ar notarine forma sudarytų sutarčių) apie pajamas pateikimas, nesant realaus pajamų gavimo fakto, patvirtinto visapusiška pajamų gavimo faktinių aplinkybių analize, paties pajamų gavimo nepagrindžia ${ }^{40}$.

Iš teismų praktikos matyti, kad, siekiant mokestinès naudos, dažnai ịvykę sandoriai (ūkinès operacijos) įforminami taip, kad jų išraiška neatitinka realaus ekonominio (socialinio) turinio, t. y. šiais sandoriais siekiama nuslèpti realiai įvykdytus sandorius ar kitas ūkines operacijas.

Galimi ir tam tikri nebūtini tarpiniai sandoriai (ūkinès operacijos) susijusių sandorių (ūkinių operacijų) grandinejje dèl to paties objekto (jo dalies), neretai sudaromi (ūkinès operacijos - atliekamos) siekiant sumažinti mokètiną mokesčio sumą arba visiškai išvengti mokesčio mokèjimo. Tai, jog sudarant tokius sandorius (atliekant ūkines operacijas) siekiama mokestinès naudos, kartu su kitomis aplinkybėmis, gali liudyti santykinai trumpas laiko tarpas tarp sandorių (ūkinių operacijų) susijusių sandorių (ūkinių operacijų) grandinejje. Jau vien per trumpą laiką įvykusių sandorių daugetas, nesant kitų aplinkybių, patvirtinančių tokių sandorių būtinumą, manytina, yra pakankamas pagrindas taikyti turinio viršenybės prieš formą principą, t. y. taikyti Mokesčių administravimo įstatymo 69 straipsnio 1 dalį ${ }^{41}$.

37 LVAT $2011 \mathrm{~m}$. vasario $23 \mathrm{~d}$. nutartis administracinejje byloje Nr. A575-371/2011 [interaktyvus]. [žiūrèta 2013-10-08]. <www.lvat.lt>.

38 LVAT $2008 \mathrm{~m}$. liepos 18 d. nutartis administracineje byloje Nr. A502-1305/2008, ibid.

39 LVAT $2008 \mathrm{~m}$. gegužès $29 \mathrm{~d}$. nutartis administracineje byloje Nr. A525-828/2008, ibid.

40 LVAT $2011 \mathrm{~m}$. vasario $4 \mathrm{~d}$. nutartis administracinèje byloje Nr. A438-201/2011 [interaktyvus]. [žiūrèta 2013-10-10]. <www.lvat.lt>.

41 LVAT $2008 \mathrm{~m}$. vasario 20 d. sprendimas administracinèje byloje Nr. A556-250/2008, taip pat $2011 \mathrm{~m}$. vasario 4 d. nutartis administracineje byloje Nr. A438-201/2011, ibid. 
Aplinkybès, jog sudarant tarpinius sandorius (atliekant ūkines operacijas) yra siekiama mokestinès naudos, nustatymui yra labai svarbūs tiek mokesčių mokètojo, tiek kitos sandorio (ūkinès operacijos) šalies veiksmai. Kaip pažymèjo Vyriausiojo administracinio teismo teisèjų kolegija administracinėje byloje Nr. A8-1844/2005, vienokio ar kitokio tikslo kaip subjektyvaus faktoriaus nustatymas yra galimas tik analizuojant faktiškai atliktus mokesčio mokètojo veiksmus, kuriais ir yra igyvendinami mokesčio mokètojo turèti tikrieji tikslai.

Tam tikrais atvejais, tai, kad yra siekiama mokestinès naudos gali patvirtinti ir ta aplinkybè, kad po turto perleidimo tarpiniu sandoriu (ūkine operacija) pradinis turto savininkas toliau valdo, naudoja, disponuoja perleistu turtu bei atlieka aktyvius veiksmus, sudarydamas galutinị turto perleidimo sandorị (ūkinę operaciją).

Galimi atvejai, kai pirminis lèšų savininkas pats asmeniškai turtą perduoda ne tarpinio, bet galutinio sandorio (ūkinės operacijos) dalyviui. Pavyzdžiui, administracinèje byloje Nr. A438-201/2011, kaip vieną iš pagrindų pripažinti, jog sudarant dovanojimo sutartis tarp dukters ir motinos bei tarp motinos ir sūnaus buvo siekiama mokestinès naudos (kartu su kitais įrodymais), teisėjų kolegija pripažino aplinkybę, jog padovanotos piniginès léšos apdovanotajam pagal pirmaji dovanojimo sandorị (motinai) realiai net nebuvo perleistos, nes dovanotojas (pagal pirmaji sandori - sesuo) jas tiesiogiai pervedè i galutinio gavejjo (apdovanotojo pagal antraji sandorị - brolio) atsiskaitomają sąskaitą ${ }^{42}$.

Tam tikrais atvejais mokestinès naudos siekị gali patvirtinti didelis skirtumas tarp sandorio (ūkinės operacijos) ir realios turto vertės (turto pirkimo-pardavimo, nuomos) ir kitos sandorių ekonomini nepagrịstumą (nelogiškumą) įrodančios aplinkybès, tačiau šios aplinkybės savaime neįrodo mokestinès naudos siekimo ir turi būti vertinamos visų faktinių aplinkybių kontekste. Sprendžiant, ar tam tikrų sandorių pagrindu ir (ar) ūkinių operacijų metu mokesčių mokètojo sumokètos sumos priskirtinos mokestinę prievolę mažinančioms išlaidoms (ekonominès (apmokestinamos) veiklos sąnaudoms), t. y. ar sandoriai atlikti ne siekiant mokestinès naudos, turi būti atsižvelgtą ị ekonominio pagrịstumo (ekonominès logikos) aspektą.

Nustačius klaidą ar formalių reikalavimų nesilaikymą, mokesčio apskaičiavimas turi būti atliekamas pagal Mokesčių administravimo įstatymo 69 straipsnio 2 dalị, nustatančią, kad tais atvejais, kai, ịformindamas apskaitos dokumentus ir pateikdamas mokesčio deklaraciją, mokesčių mokètojas suklysta, taip pat kitais atvejais, kai mokesčio mokètojo veikla neatitinka formalių teisès aktų reikalavimų, tačiau jos turinys atitinka aplinkybes, su kuriomis mokesčių įstatymai sieja apmokestinimą, mokestis apskaičiuojamas taikant minètų mokesčių ịstatymų atitinkamas nuostatas. Vadinasi, vien formalus apskaitos dokumentų trūkumas, kai ūkinès operacijos realumas (turinys) nekelia abejonių, nèra besąlyginè vada paneigti mokesčio mokètojo teisei i tam tikrą mokestinę lengvatą ar atitinkamo mokesčio atskaitą.

Analizuojant turinio viršenybès prieš formą principo taikymo procesą būtina atskleisti draudimo piktnaudžiauti teise turini, t. y. siekiant kvalifikuoti draudimą piktnau-

42 LVAT $2011 \mathrm{~m}$. vasario 4 d. nutartis administracinèje byloje Nr. A438-201/2011 [interaktyvus]. [žiūrèta 2013-10-08]. <www.lvat.lt>. 
džiauti teise, mokesčių teisès doktrinoje ir teismų praktikoje pripažįstama, jog asmuo, igyvendindamas savo teises ir naudodamasis savo laisvėmis, privalo laikytis Konstitucijos ir įstatymų, nevaržyti kitų žmonių teisių ir laisvių. Teisė neturètų ginti asmens, kuris piktnaudžiauja mokesčių teisès aktais. Konstitucinis Teismas 2003 m. lapkričio 17 d. nutarime yra pažymėjęs, kad mokesčiai turi būti apskaičiuojami sąžiningai, kad draudžiama mokesčio įstatymo nustatytą prievolę pažeisti piktnaudžiavimu, kad esant piktnaudžiavimui mokesčio administratorius, nustatydamas mokesčio bazę, atkuria iškreiptas ar slepiamas aplinkybes, kad mokesčių mokètojas turi konstitucinę pareigą sąžiningai mokèti mokesčius ${ }^{43}$.

Draudimas piktnaudžiauti teise yra bendrasis teisès principas. Šio bendrojo principo egzistavimą pagrindžia ir Teisingumo Teismo praktika ${ }^{44}$. Piktnaudžiaujant teise sukurtos teisinès pasekmès nepripažistamos ir neginamos ${ }^{45}$. Piktnaudžiavimu mokesčių įstatymais dirbtinai sukuriama teisinè situacija, lemianti mokestinę naudą (mokestinị pranašumą). Tokios mokestinès naudos igijimas pažeidžia mokesčių visuotinio privalomumo, mokesčių mokètojų lygybès principus ${ }^{46}$, nes mokesčių nemokantys subjektai konkurencine prasme atsiduria geresneje padètyje nei juos mokantys. Šiuos principus pažeidžianti veikla negali būti laikoma teisèta veikla ${ }^{47}$. Draudimas piktnaudžiauti teise yra bendrasis teisès principas ir jo taikymas laiko požiūriu yra neribotas, todèl, konstatuodami piktnaudžiavimą, mokesčių administratorius ar mokestinius ginčus nagrinëjantys subjektai neprivalo nurodyti teisès normų, suteikiančių jiems tokią teisę. Mokesčių mokètojo piktnaudžiavimą leidžiančios konstatuoti teisès normos gali tik detalizuoti nustatyto piktnaudžiavimo teisines pasekmes, tačiau jų nebuvimas negali paneigti mokesčių administratoriaus teisès pripažinti dẻl piktnaudžiavimo sandoriais kilusias teisines pasekmes.

Darytina išvada, kad piktnaudžiavimas mokesčių ịstatymais gali būti nustatytas tik tada, kai mokestinio pranašumo ịgijimas buvo pagrindinis ūkinėmis operacijomis siekiamas tikslas, o mokesčių mokètojo veikla, lemianti mokestinio pranašumo atsiradimą, negali būti pateisinta nei ekonominès logikos, pasireiškiančios didžiausio pelno siekimu mažiausiomis sąnaudomis, nei kitomis aplinkybėmis ${ }^{48}$.

Piktnaudžiavimo teise (pvz., PVM atskaita) koncepciją Teisingumo Teismas apibrèžè Halifax byloje ${ }^{49}$. Piktnaudžiavimo PVM atskaita atvejai yra tokie, kai mokesčių mokètojas sukuria transakcijų eigą nesiejant jų su ekonominiu pagrindimu, pagrindinis

43 LVAT $2011 \mathrm{~m}$. vasario 4 d. nutartis administracinèje byloje Nr. A438-201/2011 [interaktyvus]. [žiūrèta 2013-10-24]. <www.lvat.lt>.

44 Europos Teisingumo Teismo 2000 m. gruodžio 14 d sprendimas byloje Emsland-Starke Nr. C-110/99 [interaktyvus]. [žiūrèta 2013-11-06]. <http://eur-lex.europa.eu>.

45 Valančius, V.; Brazdeikis, A. Kitoks požiūris ị nuostolius dèl piktnaudžiavimo civiliniu procesu. $J u-$ risprudencija. 2011, 18(4): 1469.

46 Lietuvos Respublikos mokesčiu administravimo įstatymas, supra note 19.

47 LVAT $2004 \mathrm{~m}$. spalio 27 d. plenarinès sesijos nutartis administracineje byloje Nr. A1-355/2004. Administraciniu teismu praktika. 2004, 6: 128-143 [interaktyvus]. [žiūrèta 2013-10-08]. <www.lvat.lt>.

48 LVAT $2011 \mathrm{~m}$. vasario $23 \mathrm{~d}$. nutartis administracineje byloje Nr. A575-371/2011, taip pat $2006 \mathrm{~m}$. balandžio 6 d. nutartis administracinèje byloje Nr. A444-794/2006, ibid.

49 Europos Teisingumo Teismo $2006 \mathrm{~m}$. vasario $21 \mathrm{~d}$. sprendimas byloje Halifax Nr. C-255/02 [interaktyvus]. [žiūrèta 2013-11-06]. <http://eur-lex.europa.eu> . 
tokių veiksmų tikslas yra mokestinès naudos ịgijimas. Teisingumo Teismas suformulavo piktnaudžiavimo teise taisykles dèl PVM mokesčio, būtent konstatavo, kad piktnaudžiavimas bus tuomet, kai bus nustatytos dvi būtinos sąlygos: 1) transakcija atitinka formaliąsias sąlygas, nustatytas Šeštojoje direktyvoje bei nacionalinès teisès aktuose, dèl to yra įgyjamas mokestinis pranašumas, kuris prieštarauja Šeštosios direktyvos tikslams; 2) pagrindinis transakcijų tikslas yra mokestinio pranašumo ịgijimas, tačiau transakcija neturi ekonominio ir verslo pagrindimo.

Analizuojant piktnaudžiavimo teise instituto turinị taip pat labai svarbi yra sąžiningumo koncepcija. Ji Teisingumo Teismo sprendimuose yra nurodoma tose bylose, kuriose yra pasisakoma dèl galimybės riboti teisę $i$ atskaitą tuomet, kai subjektai dalyvauja PVM sukčiavime.

Teisingumo Teismas sąžiningumo koncepciją pradèjo formuoti sujungtose bylose Optigen Ltd, Fulcrum Electronics Ltd. ir Bond House Systems Ltd., kuriose Teismas pripažino, kad mokesčio mokètojo teisè į atskaitą negali priklausyti nuo to, kokiu būdu tiekimų grandineje veikia kiti subjektai. Teisingumo Teismas konstatavo, kad jeigu mokesčių mokètojas nežino apie kitų mokesčių mokètojų vykdomą PVM sukčiavimą, tai jam negali atsirasti neigiamos pasekmès. Teisingumo Teismas pažymejjo, kad faktas dèl to, ar mokètinas mokestis buvo sumokètas ị valstybès biudžetą, neturi įtakos teisès ị atskaitą igyvendinimui ${ }^{50}$.

Sąžiningumo koncepciją Teisingumo Teismas ịtvirtino sprendime, priimtame sujungtose bylose Axel Kittel ir Recolta Recycling ${ }^{51}$. Šiose sujungtose bylose buvo nagrinèjami du aspektai: sąžiningumas ir sutarties negaliojimas pagal nacionalinès civilinès teisès normas. Teisingumo Teismas sujungtose bylose Axel Kittel ir Recolta Recycling nesutiko su mokesčių administratoriumi ir, vadovaudamasis PVM neutralumo principu, pasisakè, kad teisès $\mathfrak{i}$ atskaitą ribojimas vadovaujantis nacionalinèmis civilinès teisès normomis, iš kurių atsiranda sandorių negaliojimas, prieštarautų Šeštosios direktyvos tikslams. Taip pat pažymėjo, kad mokesčių mokètojui, kuris nežino, kad dalyvauja mokesčiu sukčiavime, ir kuris elgdamasis rūpestingai negali to žinoti, negali būti ribojama teisè ị atskaitą tik todèl, kad paaiškejjo tiekèjo nesąžiningumas ${ }^{52}$. Sąžiningumo koncepcija Teisingumo Teismo praktikoje toliau plètojama $2012 \mathrm{~m}$. gruodžio $6 \mathrm{~d}$. sprendime byloje Bonik ${ }^{53}$, taip pat $2012 \mathrm{~m}$. birželio $21 \mathrm{~d}$. sprendime sujungtose bylose Mahagében ir David $^{54}$.

Iš viso to išplaukia, kad Teisingumo Teismas dèl sąžiningumo koncepcijos pasisako tuomet, kai sandorių tiekimo grandinèje susiduriama su apgaule atliktais teisei priešingais veiksmais, pavyzdžiui, su klaidingų deklaracijų pateikimu, neteisingų sąskaitų

50 Europos Teisingumo Teismo 2006 m. sausio 12 d. sprendimai bylose Optigen Ltd. Nr. C-354/03, Fulcrum Electronics Ltd. Nr. C-355/03 ir Bond House Systems Ltd. Nr. C-484/03 [interaktyvus]. [žiūrèta 2013-1104]. $<$ http://eur-lex.europa.eu $>$.

51 Europos Teisingumo Teismo 2006 m. liepos 6 d. sprendimai bylose Axel Kittel Nr. C-439/04 ir Recolta Recycling Nr. C-440/04, ibid.

52 Ibid.

53 Europos Teisingumo Teismo $2012 \mathrm{~m}$. gruodžio 6 d. sprendimas byloje Bonik Nr. C-285/11, ibid.

54 Europos Teisingumo Teismo 2012 m. birželio 21 d. sprendimas bylose Mahagében Nr. C-80/11 ir David C-142/11, ibid. 
faktūrų išrašymu ar realių sandorių atlikimu turint tikslą nesumokėti iš PVM apmokestinamo sandorio gauto PVM, tai yra tikslingai siekiant pasisavinti PVM.

Pažymėtina, kad apmokestinamasis asmuo, kuris žinojo arba turëjo žinoti, jog, issigydamas prekių, jis dalyvavo su sukčiavimu PVM srityje susijusiame sandoryje, turi būti laikomas sukčiavime dalyvaujančiu asmeniu, nepaisant to, ar perparduodamas prekes ar panaudodamas paslaugas savo apmokestinamiesiems pardavimo sandoriams jis gauna naudos.

Apibendrinus tai, kas išdèstyta, darytina išvada, kad nacionalinès institucijos ir teismai, pagal objektyvius duomenis nustatę, kad sandoriai, kuriais grindžiama teisè i mokestinę lengvatą, sudaryti piktnaudžiaujant arba nustatomas paties apmokestinamojo asmens sukčiavimas mokesčių srityje arba jei, atsižvelgus į objektyvias aplinkybes, įrodoma, kad apmokestinamasis asmuo (pirkèjas) žinojo arba turèjo žinoti, jog ịsigydamas prekes jis dalyvauja sandoryje, susijusiame su tiekejjo ar kito ūkio subjekto, dalyvaujančio šių tiekimų ar paslaugų grandinès pirkimo ar pardavimo sandoryje, atliktu sukčiavimu, turi teisę apmokestinamajam asmeniui atsisakyti suteikti teisę $i$ atskaitą, net jeigu nagrinejjamas sandoris atitinka objektyvius kriterijus, kuriais grindžiamos apmokestinamojo asmens atliekamo prekių tiekimo ir ekonominès veiklos sąvokos.

Pagal Teisingumo Teismo praktiką, apmokestinamojo asmens piktnaudžiavimas, apmokestinamojo asmens sukčiavimas ir apmokestinamojo asmens dalyvavimas sukčiavime PVM srityje yra vienas nuo kito turinio prasme besiskiriantys atvejai, savarankiškai pagrindžiantys teisès į PVM atskaitą ribojimą ${ }^{55}$.

\section{Išvados}

Turinio viršenybès prieš formą principas gali būti taikomas tik įvertinus subjektyvujji sandorio tikslą, ekonomini sandorio turinị, pasirinktą teisinę sandorio formą ir jos adekvatumą konkrečioms sąlygoms, sandorio pateisinimą - verslo motyvą, mokestinę naudą.

Palankiausiai mokesčių mokètojui turinio viršenybès prieš formą principas aiškinamas Belgijoje, nes mokestinėmis priemonėmis draudžiama kištis į civilinį teisinị sandorio vertinimą.

Kai nepakanka įrodymų patvirtinti nei mokesčių mokètojo, nei mokesčių administratoriaus nurodomas aplinkybes, sprendimas priimtinas tos šalies nenaudai, kuriai priklauso neįrodytų aplinkybių įrodinėjimo našta.

Mokesčio apskaičiavimo taikant turinio viršenybės prieš formą principą pagrindais gali būti: neįvykę sandoriai, kurie grindžiami išrašytais apskaitos dokumentais, tarpiniai ar priedangos (nebūtini) sandoriai, trumpas laiko tarpas tarp sandorių bendroje susijusių sandorių grandinèje ar per trumpą laiką ịvykusių sandorių daugetas, kai pradinis turto savininkas ir po galutinio sandorio aktyviai disponuoja turètu turtu, didelis skirtumas tarp realios - faktinès ir sandorio turto (paslaugų) vertès.

55 LVAT $2012 \mathrm{~m}$. balandžio $23 \mathrm{~d}$. išplèstinès teisëjų kolegijos nutartis administracinëje byloje Nr. $\mathrm{A}^{575}$ 1686/2012 2011 [interaktyvus]. [žiūrèta 2013-10-24]. <www.lvat.lt>. 
Piktnaudžiavimas mokesčių ịstatymais gali būti nustatytas tik tada, kai mokestinio pranašumo igijimas buvo pagrindinis ūkinèmis operacijomis siekiamas tikslas, o mokesčių mokètojo veikla, lemianti mokestinio pranašumo atsiradimą, negali būti pateisinta nei ekonominès logikos, pasireiškiančios didžiausio pelno siekimu mažiausiomis sąnaudomis, nei kitomis aplinkybėmis.

Europos Teisingumo Teismo mokestinių bylų analizès pagrindu teigtina, jog sprendžiant turinio viršenybės prieš formą taikymo būtinumą, reikšminga yra ịvertinti, ar susiklosčiusiuose mokestiniuose-teisiniuose santykiuose nèra piktnaudžiavimo teise ar sukčiavimo (dalyvavimo sukčiavime) ir ar egzistuoja sąžiningumo koncepcija.

Apmokestinamajam asmeniui atsisakytina suteikti teisę i mokestinę lengvatą, jei atsižvelgiant ị objektyvius įrodymus nustatoma, jog sandoriai, kuriais grindžiama ši teisè, sudaryti piktnaudžiaujant, nustatomas paties apmokestinamojo asmens sukčiavimas mokesčių srityje arba jei atsižvelgus ị objektyvias aplinkybes įrodoma, kad apmokestinamasis asmuo (pirkejjas) žinojo arba turèjo žinoti, jog ịsigydamas prekes jis dalyvauja sandoryje, susijusiame su tiekèjo ar kito ūkio subjekto, dalyvaujančio šių tiekimų ar paslaugu grandinės pirkimo ar pardavimo sandoryje, atliktu sukčiavimu, net jeigu nagrinejjamas sandoris atitinka objektyvius kriterijus, kuriais grindžiamos apmokestinamojo asmens, veikiančio kaip tokio, atliekamo prekių tiekimo ir ekonominės veiklos sąvokos.

\section{Literatūra}

Abgabenordnung, 1977.

Administraciniu teismu praktika. Lietuvos vyriausiojo administracinio teismo biuletenis. 2004, 6.

Belgian Incom Tax Code. 1992.

De Broe, L. International Tax Planning and Prevention of Abuse. Amsterdam, 2008.

Europos Teisingumo Teismo $2000 \mathrm{~m}$. gruodžio 14 d sprendimas byloje Emsland-Starke Nr. C-110/99. 02 [interaktyvus]. [žiūrèta 2013-11-06]. <http://eur-lex.europa.eu>.

Europos Teisingumo Teismo $2006 \mathrm{~m}$. sausio $12 \mathrm{~d}$. sprendimas byloje Fulcrum Electronics Ltd. $\mathrm{Nr}$. C-355/03.

Europos Teisingumo Teismo $2006 \mathrm{~m}$. sausio $12 \mathrm{~d}$. sprendimas byloje Bond House Systems Ltd. Nr. C-484/03.

Europos Teisingumo Teismo $2006 \mathrm{~m}$. sausio 12 d. sprendimas byloje Optigen Ltd. Nr. C-354/03.

Europos Teisingumo Teismo 2006 m. vasario 21 d. sprendimas byloje Halifax Nr. C-255/02.
Europos Teisingumo Teismo $2006 \mathrm{~m}$. liepos 6 d. sprendimas byloje Axel Kittel Nr. C-439/04.

Europos Teisingumo Teismo $2006 \mathrm{~m}$. liepos 6 d. sprendimas byloje Recolta Recycling Nr. C-440/04.

Europos Teisingumo Teismo $2010 \mathrm{~m}$. gruodžio $22 \mathrm{~d}$. sprendimas byloje Weald Leasing Ltd. Nr. C-103/09.

Europos Teisingumo Teismo 2012 m. birželio 21 d. sprendimas byloje Mahagében Nr. C-80/11.

Europos Teisingumo Teismo $2012 \mathrm{~m}$. birželio 21 d. sprendimas byloje David Nr. C-142/11.

Europos Teisingumo Teismo $2012 \mathrm{~m}$. gruodžio 6 d. sprendimas byloje Bonik Nr. C-285/11. Europos teisingumo Teismo $2013 \mathrm{~m}$. birželio 20 d. sprendimas byloje Alabaster Nr. C-653/11.

Grauberg, T. Anti-tax-avoidance Measures and Their Compliance with Community Law. Juridica International. 2009, Num. XVI. 
Gregory, V. Helvering 293 U.S 465 (19350). Justia: US Supreme Court Center [interaktyvus]. [žiūrèta 2013-11-21]. < https://supreme.justia.com/cases>.

Psaros, J.; Trotman, K. T. The impact of the type of accounting standards on preparer's judgments. 2004, Abacus, 40(1).

Kelly, L.; Gormley, A. M. Significant Worldwide Taxation Developments in 2012. 2012, 4.

Lietuvos Respublikos Konstitucija. Valstybès žinios. 1992, Nr. 33-1014.

Lietuvos Respublikos mokesčių administravimo istatymas. Valstybès žinios. 2004, Nr. 63-2243. Lietuvos vyriausiojo administracinio teismo $2004 \mathrm{~m}$. spalio $27 \mathrm{~d}$. plenarinès sesijos nutartis administracinèje byloje Nr. A1-355/2004.

Lietuvos vyriausiojo administracinio teismo $2005 \mathrm{~m}$. balandžio $27 \mathrm{~d}$. nutartis administracineje byloje Nr. A15-485/2005.

Lietuvos vyriausiojo administracinio teismo $2005 \mathrm{~m}$. spalio $5 \mathrm{~d}$. nutartis administracineje byloje Nr. A15-1280/2005.

Lietuvos vyriausiojo administracinio teismo $2006 \mathrm{~m}$. balandžio $6 \mathrm{~d}$. nutartis administracinèje byloje Nr. A444-794/2006.

Lietuvos vyriausiojo administracinio teismo $2007 \mathrm{~m}$. liepos $17 \mathrm{~d}$. nutartis administracinèje byloje Nr. A11-719/2007.

Lietuvos vyriausiojo administracinio teismo $2008 \mathrm{~m}$. vasario $20 \mathrm{~d}$. sprendimas administracinèje byloje Nr. A556-250/2008.

Lietuvos vyriausiojo administracinio teismo 2008 m. gegužès 29 d. nutartis administracinèje byloje Nr. A525-828/2008.

Lietuvos vyriausiojo administracinio teismo $2008 \mathrm{~m}$. liepos $18 \mathrm{~d}$. nutartis administracinèje byloje Nr. A502-1305/2008.

Lietuvos vyriausiojo administracinio teismo $2009 \mathrm{~m}$. lapkričio $30 \mathrm{~d}$. nutartis administracinejje byloje Nr. A442-1431/2009.

Lietuvos vyriausiojo administracinio teismo $2010 \mathrm{~m}$. rugsèjo $13 \mathrm{~d}$. nutartis administracinèje byloje Nr. A556-1023/2010.

Lietuvos vyriausiojo administracinio teismo $2010 \mathrm{~m}$. spalio $25 \mathrm{~d}$. nutartis administracinèje byloje Nr. A438-1147/2010.
Lietuvos vyriausiojo administracinio teismo $2011 \mathrm{~m}$. vasario $4 \mathrm{~d}$. nutartis administracinèje byloje Nr. A438-201/2011.

Lietuvos vyriausiojo administracinio teismo $2011 \mathrm{~m}$. vasario $14 \mathrm{~d}$. nutartis administracinèje byloje Nr. A438-147/2011

- Lietuvos vyriausiojo administracinio teismo $2011 \mathrm{~m}$. vasario $23 \mathrm{~d}$. nutartis administracinejje byloje Nr. A575-371/2011.

Lietuvos vyriausiojo administracinio teismo 2011 m. gegužès $24 \mathrm{~d}$. nutartis administracinejje byloje Nr. A442-1427/2011.

Lietuvos vyriausiojo administracinio teismo $2013 \mathrm{~m}$. vasario $5 \mathrm{~d}$. nutartis administracinèje byloje Nr. A602-705/2013.

Lietuvos vyriausiojo administracinio teismo $2013 \mathrm{~m}$. vasario $19 \mathrm{~d}$. nutartis administracinèje byloje Nr. A556-618/2013.

Medelienè, A.; Sudavičius, B. Mokesčiu teisè. Vilnius: Registrų centras, 2011.

Prebble, Z.; Prebble J. Comparing the General Anti-Avoidance Rule of Income Tax Law with the Civil Law Doctrine of Abuse of Law. Bulletin of International Taxation. 2008.

Psaros, J.; Trotman, K. T. TheImpact of the ype of accounting standards on preparer's judgments. Abacus. 2004, 40(1) [interaktyvus]. $<$ http://onlinelibrary.wiley.com>.

Puzinskaitè, E. Mokesčių mokètojo patikrinimas. Jurisprudencija. 2003, 38(30).

Puzinskaitè, E. Mokestiniu ginču proceso teisi$n \dot{e}$ analize. Daktaro disertacijos santrauka. Socialiniai mokslai, teisè (01S). Vilnius: Lietuvos teisès universitetas, 2002.

Puzinskaite, E. Relation of civil case with the procedure of taxinspection and tax dispute in the process of identification and investigation of shelter enterprises. The problems of the financial law evolution in central and eastern Europe within the integration processes. Vilnius-Bialystok, 2004.

Puzinskaitè, E.; Klišauskas, R. Mokesčių teisès sistema ir apmokestinimo principai. $J u$ risprudencija. 2012, 19(2).

The Constitution of Belgium. 1994.

Valančius, V.; Brazdeikis, A. Kitoks požiūris i nuostolius dèl piktnaudžiavimo civiliniu procesu. Jurisprudencija. 2011, 18(4). 
Višinskis, V. Teismo sprendimu vykdymo procesines problemos. Vilnius: Justitia, 1999.

Zalasinski, A. Proportionality of Anti-Avoidance and Anti-Abuse Measures in the ECJ Direct Tax Case Law. Interfax. 2007, (35)5.
Zimmer, F. Form and substance in tax law. Haag: Studies on International Fiscal Association, 2002.

Anotacija. Straipsnyje, pasitelkiant sistemines ir teisines analizés, istorini, logini, dokumentines analizes ir lyginamaji metodus, remiantis nacionaliniais teises, Lietuvos mokslininku ir teisès specialistu darbais, pasitelkiant mokestiniu ginču bylu analize, sprendžiamos problemos, kylančios mokesčiu teisés aiškinimo ir taikymo srityje, t. y. mokesčio apskaičiavimo taikant turinio viršenybès prieš forma principa. Straipsnyje teismu praktikos analizès pagrindu tyrinejama mokesčiu mokètojo pareiga apskaičiuoti mokesti, pateikiamos mokesčio apskaiciavimo senaties taikymo rekomendacijos, nustatomi atvejai, kuomet pareiga irodyti mokesčio apskaičiavimo teisinguma tenka mokesčiu administratoriui, kuomet - mokesčiu. mokètojui.

Reikšminiai žodžiai: mokestis, mokesčiu mokètojas, mokesčiu administratorius, mokestinè nauda, mokestinès pasekmès, mokestinis pranašumas, piktnaudžiavimas teise, ekonominis pagristumas, formali sandorio išraiška, fiktyvus sandoris, ükinès operacijos turinys.

\title{
TAX CALCULATION USING THE PRINCIPLE OF SUBSTANCE OVER FORM
}

\author{
Egidija Puzinskaitè
}

Mykolas Romeris University, Lithuania

Summary. With the help of systemic and legal analysis, historical, linguistic, logical document analysis and comparative methods and relying on national law, the works of Lithuanian scientists and legal professionals and tax dispute case analysis, this article, by applying the principle of substance over form, solves problems arising within the context of calculating tax. Using case law analysis as its basis, the article explores the taxpayer's duty to calculate tax, provides recommendations for the application of a period of limitation for calculating taxes and identifies cases, where the burden of proof of correctness of tax calculation lies within the tax administrator and within the taxpayer. The article provides taxpayers guidelines about how to avoid tax violations. The jurisdiction of the High Administrative Court in the area of tax disputes, specifically in applying the principle of substance over form, is examined in detail.

The article consists of an introduction, three chapters (which are subsequently subdivided into subchapters) and conclusions. Chapter One explores the substance of the taxpayer's duty to calculate taxes and it also includes one subchapter that analyses the application of a period of limitation for calculating and recalculating taxes. Chapter Two identifies which specific participants in tax and legal relations bear the burden of proof, namely when the burden 
of proof lies within the taxpayer and when it lies within the tax administrator. Chapter Three analyses the principle of substance over form. Chapter Four analyses the application of the principle of substance over form. The article ends with conclusions. The article has been prepared on the basis of the case law of the Lithuanian Supreme Administrative Court concerning the application of tax legislation. The aim of the study is to conclude that the principle of substance over form can be applied after assessing the subjective aim of the transaction, the economic content of the transaction, the selected legal form of the transaction and its adequacy for specific conditions, the justification or motive behind the transaction, and tax benefits. The most favourable explanation of the principle of substance over form for a taxpayer is provided in Belgium, where it is prohibited to use tax measures to interfere with the civil legal assessment of a transaction. When there is insufficient evidence to confirm the circumstances specified by either the taxpayer or the tax administrator, a resolution is adopted against the party that failed to provide proof of the circumstances. The following could be the basis for the application of substance over form in tax calculation: failed transactions based on issued accounting documents; intermediate or sham (optional) transactions; a short time interval between transactions in the common chain of transactions or plurality of transactions over a short period of time, when after the final transaction the original property owner continues to hold that property; a great difference between the actual value of the property (services) and the value of the transaction. Abuse of tax laws can be established only when a tax advantage was the main objective pursued by the underlying transactions and the taxpayer's activities that cause the tax advantage cannot be justified either by economic logic, which is demonstrated by the pursuit of maximum profit at minimum cost, or by other circumstances. On the basis of the analysis of the tax-related cases of law of the European Court of Justice, it can be stated that in deciding the need of the application of substance over form, it is important to evaluate whether there is abuse of the law or fraud (participation in the fraud) in the existing taxation and legal relations and whether there is a concept of fairness. The taxable person can be refused a right of tax exemption if according to objective evidence can be established that transactions, from which that right derives, constitute an abuse of rights, the taxable person commits a fraud or if it can be proved that the taxable person (buyer) knew or should have known that by making his purchase he is participating in the transaction relating to a fraud made by a supplier or other party participating in this chain of transaction even if this transaction corresponds to the objective criteria, which form the concepts of the supply of goods or economic performed by the taxable person.

Keywords: tax, taxpayer, tax administrator, tax benefit, tax implications, tax advantage, abuse of rights, economic feasibility, formal expression of a transaction, artificial transaction, content of an economic operation.

Egidija Puzinskaitė, Mykolo Romerio universiteto Ekonomikos ir finansų valdymo fakulteto Finansų ir mokesčių katedros lektorè, socialinių mokslų (teisè) daktarè. Mokslinių tyrimų kryptis: mokestinių ginčų teisinis procesas.

Egidija Puzinskaitė, Mykolas Romeris University, Faculty of Economics and Finance Management, Doctor of Social Sciences (Law), lecturer. Research interests: legal process of tax disputes. 